\title{
CD24 overexpression in cancer development and progression: A meta-analysis
}

\author{
JU-HAN LEE, SEO-HEE KIM, EUNG-SEOK LEE and YOUNG-SIK KIM \\ Department of Pathology, The Bioinformatics Interest Group, Korea University Ansan Hospital, Ansan, Korea
}

Received May 5, 2009; Accepted July 7, 2009

DOI: $10.3892 /$ or_00000548

\begin{abstract}
CD24 has emerged as a new oncogene and metastasis promoter. However, there is a controversy as to whether CD24 expression is a prognostic factor for poor outcomes in many human cancers. To shed light on this controversy, we performed a meta-analysis of the relationship between CD24 expression and prognostic parameters in different carcinomas. Studies published in the period 19902009 were reviewed for the meta-analysis and selected according to defined criteria. The effect sizes of prognostic parameters and overall survival were calculated by an odds ratio (OR) or an adjusted hazard ratio (HR). Twenty-eight studies reported CD24 expression for 2,925 cases. The frequency of CD24 expression by immunohistochemistry was $68 \%$ in all the carcinomas of the breast, female genital tract, gastrointestinal tract, biliary tract and pancreas, urinary system, prostate and skin. Overall, CD24 was more frequently overexpressed in their carcinomas than their benign lesions $(\mathrm{OR}=4.21 ; 95 \% \mathrm{CI}, 1.826-9.731 ; \mathrm{P}=0.001)$ and was significantly associated with lymph node metastasis $(\mathrm{OR}=2.41$; CI, 1.013-5.720; $\mathrm{P}=0.047)$, advanced clinical stages $(\mathrm{OR}=1.59$; 95\% CI, 1.244-2.032; $\mathrm{P}<0.001)$ and shortened overall survival $(\mathrm{HR}=2.13$; 95\% CI, 1.656-2.730; $\mathrm{P}<0.001)$. CD24 expression was highly associated with lymph node metastases in breast cancer $(\mathrm{OR}=3.55 ; 95 \% \mathrm{CI}, 1.664-7.554 ; \mathrm{P}=0.001)$, advanced clinical stages $(\mathrm{OR}=2.22 ; 95 \% \mathrm{CI}, 1.442-3.418 ; \mathrm{P}<0.001)$ and lymphovascular invasions $(\mathrm{OR}=2.78 ; 95 \% \mathrm{CI}, 1.522-5.068$; $\mathrm{P}=0.001)$ in urothelial carcinomas and with higher grades in endometrial adenocarcinomas $(\mathrm{OR}=3.88$; 95\% CI, 1.548-9.715; $\mathrm{P}=0.004)$. CD24 was more frequently and strongly expressed in breast $(\mathrm{OR}=35.80 ; 95 \% \mathrm{CI}, 8.907-143.921 ; \mathrm{P}<0.001)$ and ovarian carcinomas $(\mathrm{OR}=35.92 ; \mathrm{CI}, 7.156-180.311$; $\mathrm{P}<0.001)$, than in their benign counterparts. In conclusion, the metaanalysis strongly supports the idea that CD24 is an important marker of malignancy and poor prognosis in various cancers. In particular, CD24 may promote cancer development and progression in the breast, ovary and urinary bladder.
\end{abstract}

Correspondence to: Dr Young-Sik Kim, Department of Pathology, Korea University Ansan Hospital, 516, Gojan-1 Dong, Danwon-Gu, Ansan-Si, Gyeonggi-Do 425-707, Korea

E-mail: cindoc@naver.com; apysk@korea.ac.kr

Key words: CD24, carcinoma, prognosis, meta-analysis

\section{Introduction}

Accumulating evidence indicates that CD24 expression is an important biomarker for diagnosis and progression in many carcinomas (1-3). CD24 is a small 27 amino acid glycoprotein at the outer surface of the cell membrane and is attached to the cell membrane by a glycosylphosphatidyl-inositol (GPI) anchor $(1,2)$. In human tissues, CD24 protein was first reported to be expressed by pre-B lymphocytes, but it is lost during maturation to plasma cells (4). This protein had been recognized only as a cell marker for hematopoietic cell lineages.

In recent years, many studies have described CD24 expression in carcinomas arising in various organs using immunohistochemistry (5-32). Most studies reported that overexpression of CD24 protein or CD24 positivity is significantly associated with malignant transformation or poor clinicopathologic parameters in a variety of carcinomas, especially breast cancer (1-3,5-9,11-28,30,31). In contrast, several studies have suggested that the absence or low expression of CD24 might be related to tumor growth, invasiveness or metastasis in breast cancer (33-36). In addition, it has been reported that the clinicopathologic significance of CD24 is different even among the studies using the same type of carcinomas arising in the same organ (5-24). In an attempt to address these controversies, we performed a meta-analysis to examine the relationship between CD24 expression and clinicopathologic parameters.

\section{Materials and methods}

Eligibility criteria for meta-analysis. We extensively searched for studies that examined associations between CD24 expression and clinicopathological characteristics related to various carcinomas. The following type of articles were included: i) Articles demonstrating that CD24 is expressed in primary cancer tissue as indicated by immunohistochemistry; articles that dealt with cell lines or animals were excluded; ii) Articles published in English before February 2009; iii) the most informative article when multiple articles were published by the same authors or groups. The following articles were excluded: i) review articles without original data; ii) articles lacking or containing inappropriately presented data; and iii) case studies.

Collection of published studies. An extensive search for publications was carried out using the PubMed database 
Table I. Characteristics of individual studies included in the meta-analysis.

\begin{tabular}{|c|c|c|c|c|c|}
\hline Study & $\begin{array}{l}\text { Patient's } \\
\text { country }\end{array}$ & Location & $\begin{array}{c}\text { No. of } \\
\text { cases }\end{array}$ & $\begin{array}{l}\mathrm{CD} 24+\mathrm{No} . \\
(\%)\end{array}$ & Comments \\
\hline Fogel et al (5) & Israel & Breast & 31 & $31(100 \%)$ & Cancer $>$ benign \\
\hline Kristiansen et al (6) & Germany & Breast & 201 & $170(85 \%)$ & Lymph node metastasis, poor survival rate \\
\hline Surowiak et al (7) & Poland & Breast & 60 & $46(77 \%)$ & Poor survival rate \\
\hline Bircan et al (8) & Turkey & Breast & 59 & $55(93 \%)$ & Cancer $>$ benign, grade \\
\hline \multirow[t]{5}{*}{ Lim et al (9) } & Korea & Breast & 22 & $22(100 \%)$ & Cancer $>$ benign \\
\hline & & Ovary & 14 & $14(100 \%)$ & Grade \\
\hline & & Gallbladder & 14 & $12(86 \%)$ & Cancer $>$ benign \\
\hline & & Colon & 31 & $30(97 \%)$ & Cancer $>$ benign, lymph node metastasis $(\mathrm{C})$ \\
\hline & & Stomach & 48 & $43(90 \%)$ & Lymph node metastasis in AGC \\
\hline Honeth et al (10) & Sweden & Breast & 240 & $110(46 \%)$ & NA \\
\hline Athanassiadou et al (11) & Greece & Breast & 70 & $54(77 \%)$ & Grade, size, lymph node metastasis, stage \\
\hline Kristiansen et al (12) & Germany & Ovary & 56 & $51(91 \%)$ & Poor survival rate $(\mathrm{C})$ \\
\hline Choi et al (13) & Korea & Ovary & 71 & $71(100 \%)$ & Poor survival rate (C) \\
\hline Surowiak et al (14) & Poland & Ovary & 43 & $34(79 \%)$ & Poor survival rate \\
\hline Santin et al (15) & USA & Ovary & 10 & $10(100 \%)$ & NA \\
\hline Winkler et al (16) & Austria & Urinary tract & 259 & $161(62 \%)$ & Grade, angio-invasion, stage \\
\hline Choi et al (17) & Korea & Bladder & 135 & $83(61 \%)$ & Grade, stage \\
\hline Karahan et al (18) & Turkey & Endometrium & 44 & $34(77 \%)$ & Grade, lymph node metastasis, stage \\
\hline Kim et al (19) & Korea & Endometrium & 82 & $53(64 \%)$ & Grade \\
\hline Su et al (20) & Taiwan & Biliary tract & 70 & $36(51 \%)$ & Poor survival rate \\
\hline Baumhoer et al (21) & Switzerland & Ampulla of Vater & 152 & $83(55 \%)$ & Cancer $>$ benign \\
\hline Sagiv et al (22) & Israel & Colorectal & 66 & $57(86 \%)$ & Cancer $>$ normal \\
\hline Weichert et al (23) & Germany & Colorectal & 147 & $124(84 \%)$ & $\begin{array}{l}\text { Grade, lymph node metastasis, stage, poor } \\
\text { survival rate }(\mathrm{C})\end{array}$ \\
\hline Chou et al (24) & Taiwan & Stomach & 103 & $63(61 \%)$ & $\begin{array}{l}\text { Stage, lymphovascular invasion, poor } \\
\text { survival rate }(C)\end{array}$ \\
\hline Kristiansen et al (25) & Germany & Lung & 89 & $68(76 \%)$ & Poor survival rate \\
\hline Kristiansen et al (26) & Germany & Prostate & 102 & $49(48 \%)$ & Stage, poor survival rate \\
\hline Sano et al (27) & Japan & Esophagus & 151 & $61(40 \%)$ & $\begin{array}{l}\text { Lymph node metastasis, stage, poor } \\
\text { survival rate }\end{array}$ \\
\hline Lee et al (28) & Korea & Kidney & 328 & $201(61 \%)$ & $\begin{array}{l}\text { Grade, size, poor progression free survival } \\
\text { rate }\end{array}$ \\
\hline Droz et al (29) & France & Kidney & 28 & $28(100 \%)$ & NA \\
\hline Kwon et al (30) & Korea & Uterine cervix & 73 & $43(59 \%)$ & Poor distant metastasis free survival rate \\
\hline Jacob et al (31) & Germany & Pancreas & 95 & $68(72 \%)$ & Grade \\
\hline Deichmann et al (32) & Germany & Skin & 31 & $29(94 \%)$ & NA \\
\hline Total & & & 2925 & $1994(68 \%)$ & \\
\hline
\end{tabular}

No., number; +, positive (membranous or cytoplasmic); cancer > benign, CD24 is increased in carcinoma compared to benign lesions; C, cytoplasmic expression; AGC, advanced gastric cancer; NA, not available; cancer > normal, CD24 is increased in carcinoma compared to normal.

(http://www.ncbi.nlm.nih.gov/pubmed). The keywords for our search consisted of 'CD24 + cancer' and 'CD24 + carcinoma', which retrieved 439 and 97 citations, respectively. We selected relevant studies on the basis of the summary analysis. We avoided obtaining duplicate data by carefully examining the authors' names and affiliations for each publication. Overlapping articles and articles unrelated to our analysis were excluded.

Data pooling and statistics. Meta-analysis was performed, as previously described (37). An effect size for each of the studies analyzed was estimated by an odds ratio (OR) using the Mantel-Haenszel method or a hazard ratio (HR). The choice to use a random or fixed effect model for analysis depended on Q statistics. Statistical analysis was performed using Comprehensive Meta-analysis Software version 2.0 (Biostat, Englewood, NJ, USA); P-values $<0.05$ were considered statistically significant.

\section{Results}

Twenty-eight studies satisfied the selection criteria (5-32). The main features of the chosen studies are described in Table I. The selected studies included a total of 2,925 cases, and ranged from 10 to 328 patients. CD24 overexpression was found in 1,994 (68\%) of the 2,925 patients. Ectopic 


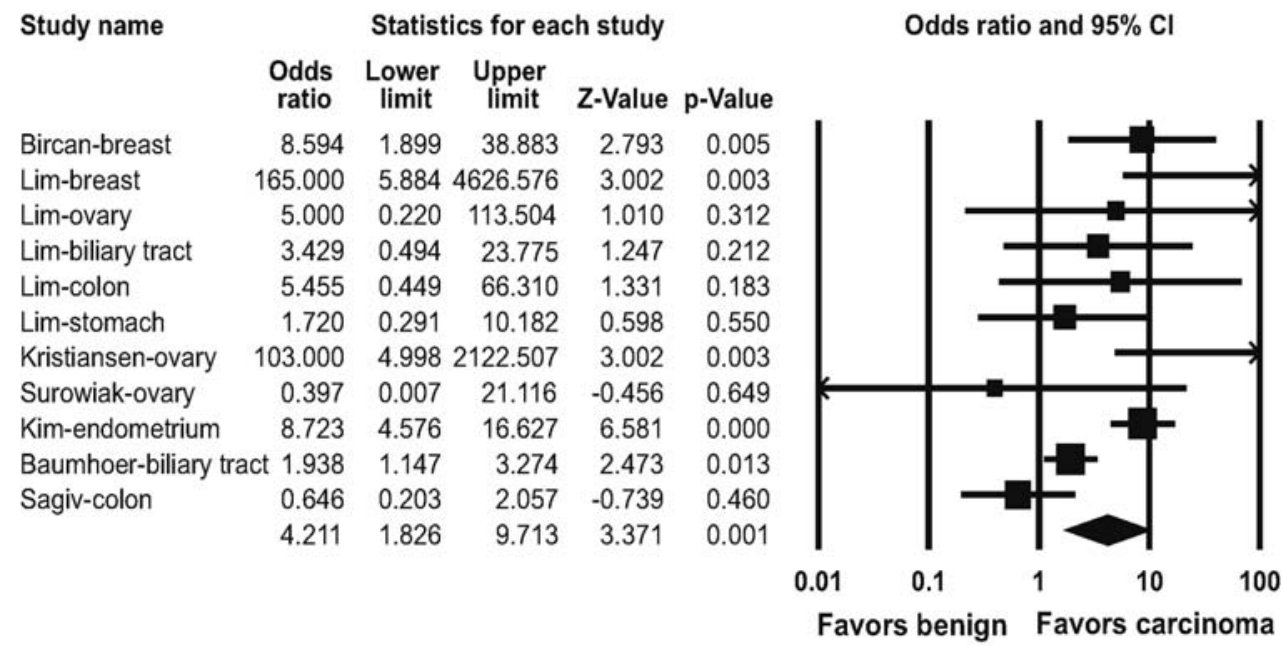

Figure 1. Odds ratios with corresponding 95\% confidence intervals for individual studies and pooled data for the association of CD24 expression with benign lesions and carcinomas. The graph demonstrates effect sizes and 95\% confidence intervals for each study and overall.

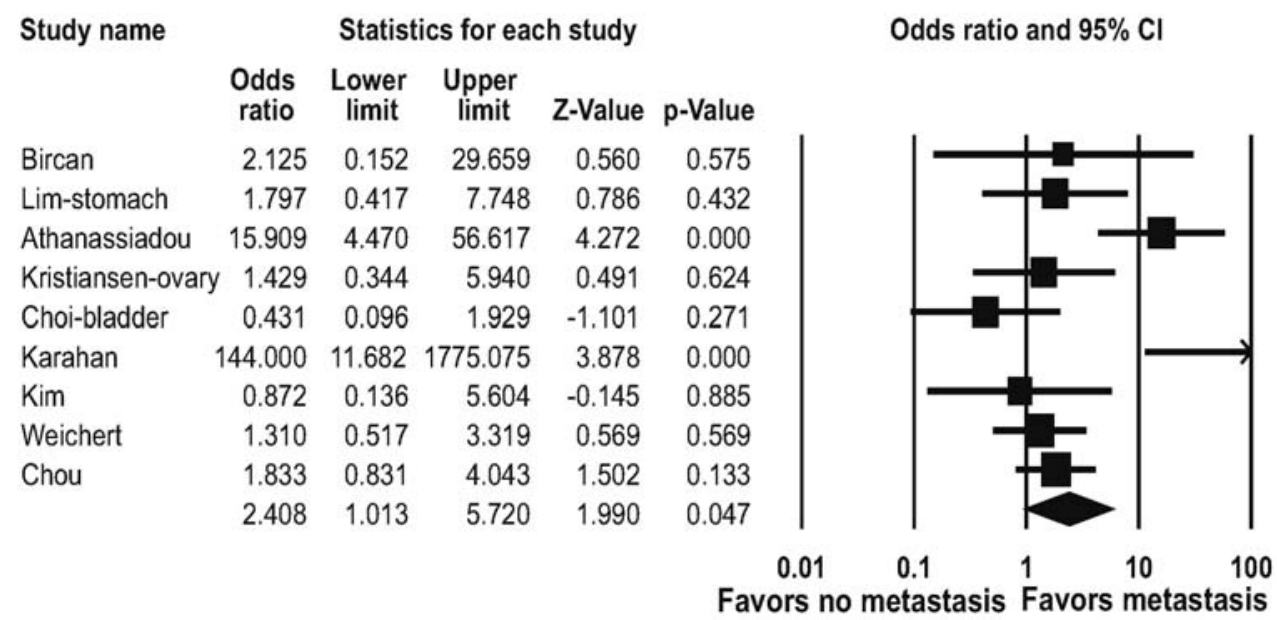

Figure 2. Pooled estimates of the association between cytoplasmic CD24 expression and lymph node metastasis.

expression of CD24 in the cytoplasm was observed in 805 (57\%) of 1,409 patients. Seven studies presented CD24 comparisons between benign and malignant lesions $(8,9,12,14,19,21,22)$. CD24 expression was detected in 432 $(74 \%)$ of 587 carcinomas and in $158(45 \%)$ of 351 benign lesions. There was significant statistical heterogeneity among the studies $(\mathrm{Q}=33.924, \mathrm{df}=10, \mathrm{P}<0.001) . \mathrm{CD} 24$ expression was upregulated more in carcinomas than in benign lesions $(\mathrm{OR}=4.211,95 \% \mathrm{CI}, 1.826-9.731 ; \mathrm{P}=0.001)$ (Fig. 1).

Fifteen studies reported the relationship of CD24 expression to lymph node metastasis $(6,8,9,11,18-20,23,25-28,30-32)$. CD24 expression was found in $376(70 \%)$ of 538 cases with lymph node metastasis and in $522(53 \%)$ of 994 cases without lymph node metastasis. Significant statistical heterogeneity was found among the studies $(\mathrm{Q}=34.607, \mathrm{df}=14, \mathrm{P}=0.002)$. CD24 expression was not associated with lymph node metastasis $(\mathrm{OR}=1.485,95 \% \mathrm{CI}, 0.909-2.426$; $\mathrm{P}=0.114)$. However, nine studies reported the association of cytoplasmic staining of CD24 with lymph node metastasis $(8,9,11,12,17-19,23,24)$. The cytoplasmic expression of
CD24 was found in 172 (70\%) of 244 cases with lymph node metastasis and in $173(51 \%)$ of 336 cases without lymph node metastasis. There was significant statistical heterogeneity among the studies $(\mathrm{Q}=27.232, \mathrm{df}=8, \mathrm{P}=0.001)$. CD24 expression in the cytoplasm was more associated with lymph node metastasis $(\mathrm{OR}=2.408,95 \% \mathrm{CI}, 1.013-5.720 ; \mathrm{P}=0.047)$ (Fig. 2).

Thirteen studies investigated the relationship of CD24 expression to clinical stage $(6,7,11,16,18,20,23,25-28,30,31)$. CD24 was detected in 318 (62\%) of 511 cases with stages III or IV, whereas it was found in $654(56 \%)$ of 1,170 cases with stages I or II. CD24 expression was associated with advanced clinical stages $(\mathrm{OR}=1.589,95 \% \mathrm{CI}, 1.244-2.032 ; \mathrm{P}<0.001)$ (Fig. 3). Heterogeneity among the studies were not statistically significant $(\mathrm{Q}=15.935, \mathrm{df}=12, \mathrm{P}=0.194)$.

Eight studies including 1,133 patients reported exact HRs and CIs on overall survival adjusted for other prognostic factors according to total (membranous and/or cytoplasmic) or cytoplasmic CD24 expression (negative or low expression vs. positive or high expression) $(6,12,13,23,25-28)$. The adjusted HRs that were estimated ranged from 1.54 to 5.37 . The 


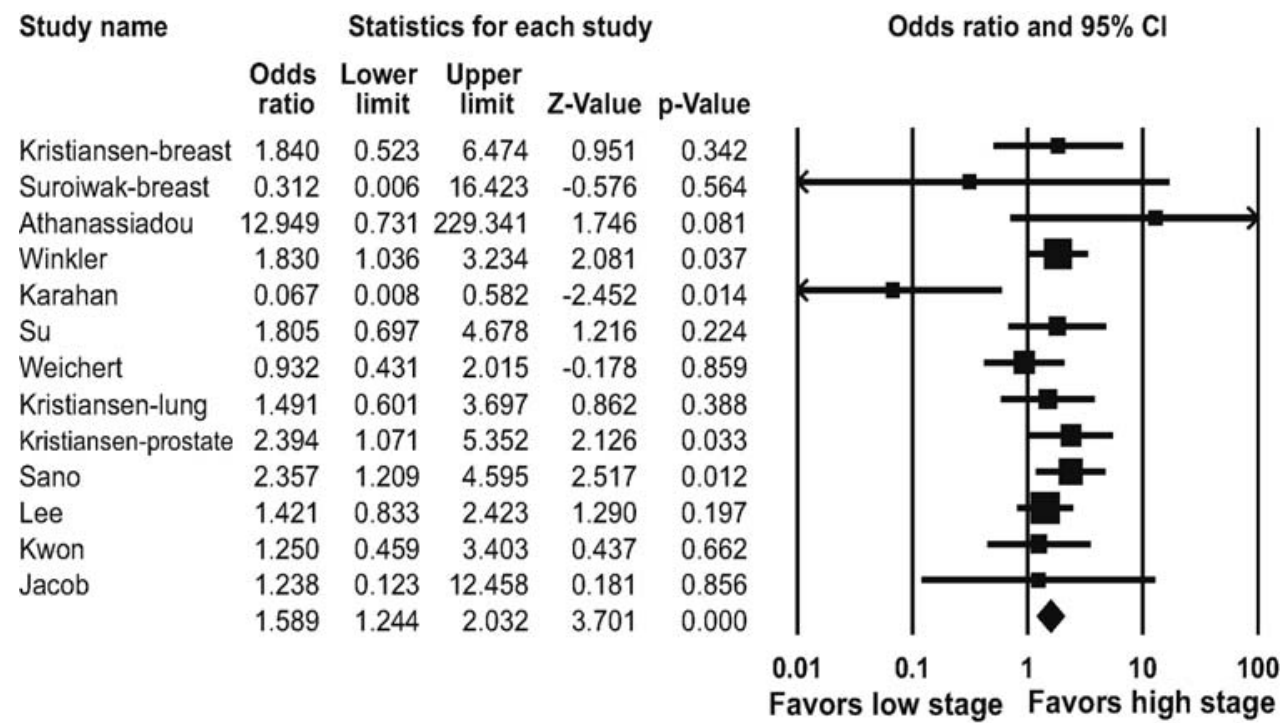

Figure 3. Pooled estimates of the association between CD24 expression and clinical stages.

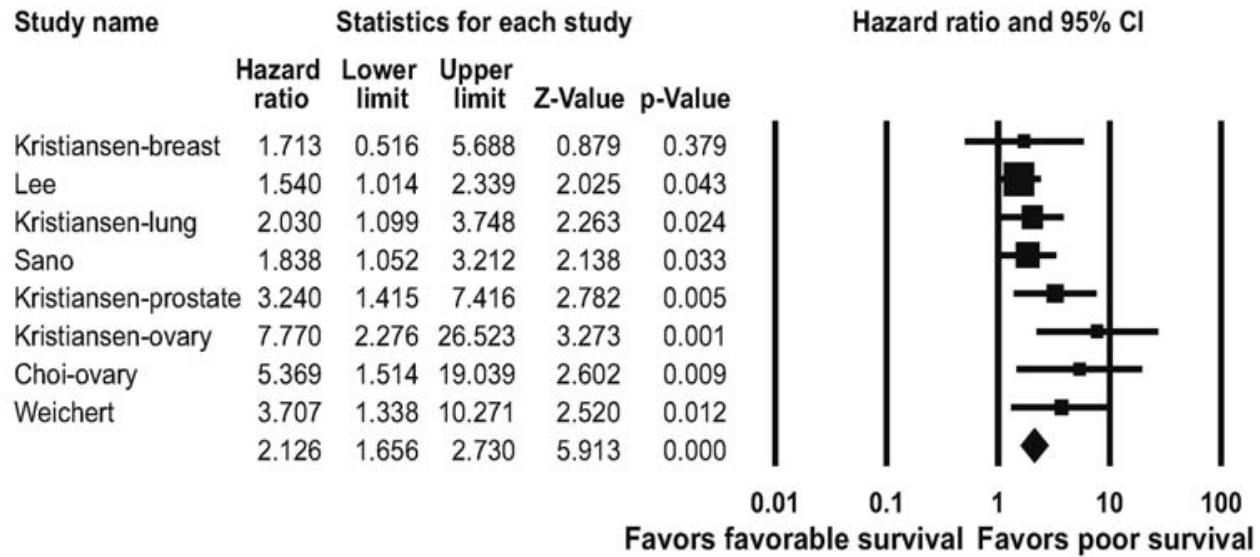

Figure 4. Hazard ratios with corresponding 95\% confidence intervals of individual studies and pooled data for the association between CD24 expression and overall survival in a variety of carcinomas.

pooled HR for these studies was $2.126(95 \%$ CI, 1.656-2.730; $\mathrm{P}<0.001$ ) (Fig. 4). Heterogeneity among the studies were not statistically significant $(\mathrm{Q}=11.170, \mathrm{df}=7, \mathrm{P}=0.131)$.

Breast cancer. Seven studies presented CD24 expression in breast cancer patients (5-11). Out of 683 patients with breast cancer, CD24 expression was found in 488 (71\%) patients while CD24 expression in the cytoplasm was observed in $422(62 \%)$ cases. Three studies investigated cytoplasmic CD24 expression between benign and malignant lesions $(5,8,9)$. Cytoplasmic staining of CD24 was found in $86(78 \%)$ of 110 malignant lesions and in $2(8 \%)$ of 25 benign lesions. CD24 expression in the cytoplasm was highly and significantly greater in carcinomas than in benign lesions $(\mathrm{OR}=35.803$, 95\% CI, 8.907-143.921; $\mathrm{P}<0.001$ ) (Fig. 5). No significant heterogeneity was found among the studies $(\mathrm{Q}=4.235, \mathrm{df}=2$, $\mathrm{P}=0.120)$.

Three studies reported on the association of total CD24 expression with lymph node metastasis $(6,8,11)$. CD24 expression was found in 151 (93\%) of 162 cases with lymph node metastasis and in $92(71 \%)$ of 130 cases without lymph node metastasis. High expression of CD24 was significantly associated with lymph node metastasis $(\mathrm{OR}=3.546,95 \% \mathrm{CI}$, 1.664-7.554; $\mathrm{P}=0.001$ ) (Fig. 6). There was no significant heterogeneity in two studies $(\mathrm{Q}=5.113, \mathrm{df}=2, \mathrm{P}=0.078)$.

Three studies described CD24 expression according to tumor size (T3, 4 vs. T1, 2) $(6,8,11)$, grade $(3$ vs. 1, 2) $(6,8,11)$, clinical stage (III, IV vs. I, II) $(6,7,11)$, or ER status and c-erbB2 expression (6,8). Tumor size $(\mathrm{OR}=1.347,95 \%$ CI, 0.442-4.108; $\mathrm{P}=0.601)$, grade $(\mathrm{OR}=1.681,95 \% \mathrm{CI}$, $0.730-3.870 ; \mathrm{P}=0.222)$, clinical stage $(\mathrm{OR}=2.140,95 \% \mathrm{CI}$, 0.708-6.471; $\mathrm{P}=0.178)$, ER status $(\mathrm{OR}=0.572,95 \% \mathrm{CI}$, $0.233-1.405 ; \mathrm{P}=0.223)$ and $\mathrm{c}-\mathrm{erbB} 2(\mathrm{OR}=2.213,95 \% \mathrm{CI}$, $0.797-6.145 ; \mathrm{P}=0.127$ ) expression were not associated with CD24 expression.

Ovarian cancer. Five studies addressed membranous CD24 expression in ovarian cancer patients $(9,12-15)$. Membranous CD24 expression was detected in 158 (81\%) of 194 ovarian cancer patients. Four studies presented cytoplasmic CD24 expression among benign, borderline and malignant lesions (9,12-14). Cytoplasmic staining of CD24 was observed in 
Study name

$\begin{array}{lrrrrr} & \begin{array}{r}\text { Odds } \\ \text { ratio }\end{array} & \begin{array}{c}\text { Lower } \\ \text { limit }\end{array} & \begin{array}{c}\text { Upper } \\ \text { limit }\end{array} & \text { Z-Value } & \text { p-Value } \\ \text { Fogel } & 767.000 & 13.896 & 42334.305 & 3.246 & 0.001 \\ \text { Lim } & 4.086 & 0.197 & 84.716 & 0.910 & 0.363 \\ \text { Bircan } & 40.857 & 7.458 & 223.821 & 4.275 & 0.000 \\ & 35.803 & 8.907 & 143.921 & 5.041 & 0.000\end{array}$

Odds ratio and $95 \% \mathrm{Cl}$

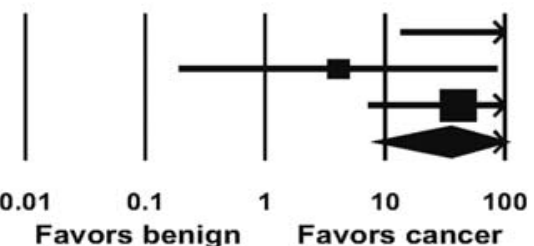

Figure 5. Pooled estimates of the association of cytoplasmic CD24 expression between benign lesions and carcinomas of the breast.

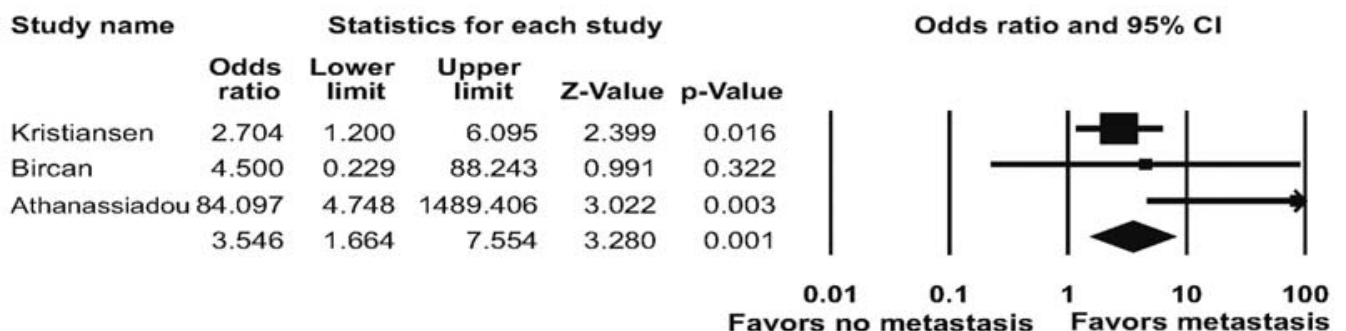

Figure 6. Pooled estimates of the association between CD24 expression and lymph node metastasis of breast cancer.

Study name

$\begin{array}{lrrr} & \begin{array}{r}\text { Odds } \\ \text { ratio }\end{array} & \begin{array}{c}\text { Lower } \\ \text { limit }\end{array} & \begin{array}{c}\text { Upper } \\ \text { limit }\end{array} \\ \text { Lim } & 43.154 & 2.163 & 860.810 \\ \text { Kristiansen } & 15.681 & 0.827 & 297.419 \\ \text { Choi } & 893.000 & 33.889 & 23531.407 \\ \text { Surowiak } & 1.047 & 0.020 & 55.131 \\ & 35.920 & 7.156 & 180.311\end{array}$

Statistics for each study

Z-Value p-Value

$2.465 \quad 0.014$

$\begin{array}{ll}1.833 & 0.067\end{array}$

$4.071 \quad 0.000$

$0.022 \quad 0.982$

4.351
Odds ratio and $95 \% \mathrm{Cl}$

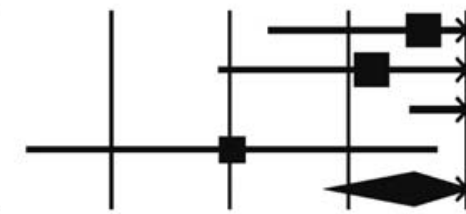

$\begin{array}{lllll}0.01 & 0.1 & 1 & 10 & 100\end{array}$

Favors adenoma Favors carcinoma

Figure 7. Pooled estimates of the association of cytoplasmic CD24 expression between adenomas and carcinomas in the ovary.

\begin{tabular}{lrrrrrr} 
Study name & \multicolumn{5}{c}{ Statistics for each study } \\
& $\begin{array}{l}\text { Odds } \\
\text { ratio }\end{array}$ & $\begin{array}{c}\text { Lower } \\
\text { limit }\end{array}$ & $\begin{array}{c}\text { Upper } \\
\text { limit }\end{array}$ & Z-Value & p-Value \\
Lim & 6.538 & 0.266 & 160.968 & 1.149 & 0.251 \\
Kristiansen & 10.043 & 1.156 & 87.251 & 2.091 & 0.036 \\
Choi & 194.444 & 23.437 & 1613.236 & 4.882 & 0.000 \\
Surowiak & 1.047 & 0.020 & 55.131 & 0.022 & 0.982 \\
& 22.257 & 6.110 & 81.074 & 4.704 & 0.000
\end{tabular}

Odds ratio and $95 \% \mathrm{CI}$

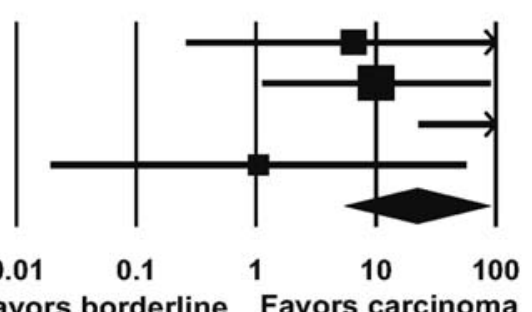

Figure 8. Pooled estimates of the association of cytoplasmic CD24 expression between borderline tumor and carcinoma in the ovary.

none $(0 \%)$ of 30 adenomas, $10(23 \%)$ of 44 borderline tumors and $133(72 \%)$ of 184 ovarian carcinomas. Cytoplasmic CD24 expression was much greater in ovarian carcinoma patients than in patients with adenomas $(\mathrm{OR}=35.920,95 \% \mathrm{CI}, 7.156-$ $180.311 ; \mathrm{P}<0.001)$ (Fig. 7) and those with a borderline tumor $(\mathrm{OR}=22.257,95 \%$ CI, 6.110-81.074; $\mathrm{P}<0.001)$ (Fig. 8).
There was no significant heterogeneity $(\mathrm{Q}=7.081, \mathrm{df}=3$, $\mathrm{P}=0.069, \mathrm{Q}=7.398, \mathrm{df}=3, \mathrm{P}=0.060)$ among the studies, respectively. Two studies reported cytoplasmic expression of CD24 between tumor grades (3 vs. 1, 2) $(12,14)$. Tumor grade $(\mathrm{OR}=1.607,95 \% \mathrm{CI}, 0.704-3.671 ; \mathrm{P}=0.260)$ was not significantly associated with cytoplasmic CD24 expression. 
Other clinicopathological parameters were not available for this meta-analysis.

Urothelial carcinoma. Two studies reported CD24 expression as a function of clinicopathologic parameters in urothelial carcinoma patients $(16,17)$. CD24 overexpression was found in $244(61.9 \%)$ of 394 urothelial carcinoma patients. CD24 overexpression was observed in $123(72 \%)$ of 170 patients with higher stages (T2-4) and in 121 (54\%) of 224 with lower stages (Ta, T1). High expression of CD24 was significantly associated with advanced clinical stages $(\mathrm{OR}=2.220,95 \% \mathrm{CI}, 1.442-3.418 ; \mathrm{P}<0.001)$. No significant heterogeneity was found in two studies $(\mathrm{Q}=1.370, \mathrm{df}=1$, $\mathrm{P}=0.242$ ).

CD24 expression was reported in $79(81 \%)$ of 97 cases with lymphovascular invasion and in 104 (61\%) of 170 cases without lymphovascular invasion. High expression of CD24 was significantly associated with lymphovascular invasion $(\mathrm{OR}=2.777,95 \% \mathrm{CI}, 1.522-5.068 ; \mathrm{P}=0.001)$. No significant heterogeneity was detected $(\mathrm{Q}=0.001, \mathrm{df}=1, \mathrm{P}=0.974)$. Tumor grade $(\mathrm{OR}=1.896,95 \% \mathrm{CI}, 0.487-7.383 ; \mathrm{P}=0.357)$ was not associated with CD24 expression. Other clinicopathological parameters were not suitable for this meta-analysis.

Endometrial cancer. Two studies presented membranous and cytoplasmic CD24 expression as a function of clinicopathologic parameters in endometrial cancer patients $(18,19)$. Membranous expression and cytoplasmic CD24 expression were found in $70(56 \%)$ and $42(33 \%)$ of 126 endometrial cancer patients, respectively. CD24 expression in the cytoplasm was observed in $30(42 \%)$ of 71 cases with grades 2 or 3 and in $9(20 \%)$ of 46 with grade 1. CD24 overexpression in the cytoplasm was significantly associated with high grade $(\mathrm{OR}=3.877,95 \% \mathrm{CI}, 1.548-9.715 ; \mathrm{P}=0.004)$. There was no significant heterogeneity in two studies $(\mathrm{Q}=0.011$, $\mathrm{df}=1, \mathrm{P}=0.918)$. Myometrial invasion $(\mathrm{OR}=0.455,95 \% \mathrm{CI}$, $0.193-1.077 ; \mathrm{P}=0.073)$, lymph node metastasis $(\mathrm{OR}=10.420$, $95 \% \mathrm{CI}, 0.070-1550.767 ; \mathrm{P}=0.359)$ and clinical stage $(\mathrm{OR}=3.629,95 \% \mathrm{CI}, 0.143-92.182 ; \mathrm{P}=0.435)$ were not associated with cytoplasmic CD24 expression.

Biliary tract carcinoma. Three studies investigated CD24 expression in patients with carcinomas of the biliary tract including the gallbladder, common and hepatic bile ducts and ampulla of Vater $(9,20,21)$. CD24 staining was found in $131(55.5 \%)$ of 236 patients. Two studies compared CD24 expression between adenoma and carcinoma $(9,21)$. CD24 overexpression was observed in 95 (57\%) of 166 carcinoma patients and in $43(41 \%)$ of 105 adenoma patients. CD24 expression was significantly greater in carcinoma than in adenoma $(\mathrm{OR}=2.015,95 \% \mathrm{CI}, 1.215-3.342$; $\mathrm{P}=0.007)$. No significant heterogeneity was detected in two studies $(\mathrm{Q}=0.311, \mathrm{df}=1, \mathrm{P}=0.577)$. Other prognostic parameters were not available for this meta-analysis.

Colorectal cancer. Three $(9,22,23)$ and two $(9,23)$ studies described membranous and cytoplasmic staining of CD24, respectively, in colorectal cancers. Membranous expression and cytoplasmic expression of CD24 were detected in 188 (77\%) of 244 and 137 (77\%) of 178 patients, respectively. Two studies compared membranous CD24 expression between adenoma and carcinoma $(9,22)$. CD24 expression was not different between adenoma and carcinoma $(\mathrm{OR}=0.942$, 95\% CI, 0.330-2.695; $\mathrm{P}=0.912$ ). Two studies compared cytoplasmic CD24 expression with lymph node metastasis $(9,23)$. Cytoplasmic expression of CD24 was not associated with lymph node metastasis ( $\mathrm{OR}=1.570,95 \% \mathrm{CI}, 0.704-3.503$; $\mathrm{P}=0.271$ ). Other parameters were not suitable for this metaanalysis.

Stomach cancer. Two studies presented CD24 expression in stomach cancers $(9,24)$. Membranous and cytoplasmic expression of CD24 were observed in $106(70 \%)$ and 60 (40\%) of 151 patients, respectively. CD24 expression in the cytoplasm was not associated with lymph node metastasis $(\mathrm{OR}=1.825$, 95\% CI, 0.910-3.659; $\mathrm{P}=0.090)$. Other prognostic parameters were not available for this meta-analysis.

\section{Discussion}

Our results indicate that CD24 expression is significantly upregulated in different carcinomas compared to their benign lesions. In addition, in many human cancers CD24 overexpression is highly associated with adverse prognostic parameters such as lymph node metastasis, advanced clinical stages and worse overall survival.

This meta-analysis suggests that CD24 plays a role in carcinogenesis of the breast and ovary. CD24 expression was increased in breast and ovarian carcinomas with ORs of 14 and 9, compared to their benign lesions. In particular, the OR of cytoplasmic CD24 expression in breast and ovarian carcinomas were increased by $\sim 36$-fold each. CD 24 expression in biliary tract carcinomas was also 2 -fold greater than in biliary adenomas. However, CD24 expression was not different between colorectal adenomas and carcinomas. The results suggest that CD24 overexpression occurs at different stages of carcinogenesis in various organs. For example, it is hypothesized that upregulation of CD24 expression might occur in late stage breast and ovarian carcinogenesis but at early stages of the colorectal adenomacarcinoma sequence.

The mechanism by which CD24 induces tumorigenesis of hormone-dependent organs including the breast and ovary remains unknown. Recently, cancer stem cells in breast and prostate cancer have been represented as $\mathrm{CD} 44^{+} / \mathrm{CD} 24^{-/ \text {low }}$, which resemble normal stem cells with respect to their ability to self-renew and to differentiate into diverse cell types $(35,36,38)$. In contrast, Li et al $(39)$ reported that CD $44^{+} / \mathrm{CD} 24^{+}$ pancreatic cancer cells exhibited stem cell properties. Therefore, CD24 is considered to be an important marker of cancer stem cells regardless of whether its expression is upregulated or downregulated.

In this meta-analysis, membranous or cytoplasmic CD24 overexpression was closely related to adverse factors such as lymph node metastases, advanced clinical stages and poor overall survival. However, the significance of CD24 overexpression was not consistent among carcinomas arising in different organs. CD24 expression was highly associated with lymph node metastases and lymphovascular invasions in breast and urothelial cancers, respectively, but not in 
endometrial, colorectal and gastric cancers. Additionally, CD24 expression was significantly related to advanced clinical stages in urothelial cancer, but not in breast and endometrial cancers.

In fact, CD24 on the cell membrane serves as a ligand for P-selectin and hence functions as an adhesion molecule that enhances platelet aggregation (1-3). CD24-expressing cancer cells can bind to P-selectin on the endothelial cells and platelets, leading to promotion of extravasation and metastasis of cancer cells (1-3). However, the exact nature of CD24 expression in the cytoplasm remains unknown and needs to be further elucidated. Several studies suggest that CD24 also participates in a signaling pathway via a regulator such as the chemokine receptor CXCR4 $(1,2,33)$.

In summary, our study indicates that CD24 is an independent prognostic factor in many human cancers. In particular, CD24 may play a role in carcinogenesis, lymph node metastasis and/or local invasion in carcinomas of the breast, ovary and urinary bladder.

\section{References}

1. Kristiansen G, Sammar M and Altevogt P: Tumour biological aspects of CD24, a mucin-like adhesion molecule. J Mol Histol 35: 255-262, 2004

2. Sagiv E and Arber N: The novel oncogene CD24 and its arising role in the carcinogenesis of the GI tract: from research to therapy. Expert Rev Gastroenterol Hepatol 2: $125-133,2008$

3. Lim SC: CD24 and human carcinoma: tumor biological aspects. Biomed Pharmacother 59 (Suppl 2): 351-354, 2005.

4. Chappel MS, Hough MR, Mittel A, Takei F, Kay R and Humphries RK: Cross-linking the murine heat-stable antigen induces apoptosis in B cell precursors and suppresses the antiCD40-induced proliferation of mature resting B lymphocytes. J Exp Med 184: 1639-1649, 1996.

5. Fogel M, Friederichs J, Zeller Y, Husar M, Smirnov A, Roitman L, Altevogt P and Sthoeger ZM: CD24 is a marker for human breast carcinoma. Cancer Lett 143: 87-94, 1999.

6. Kristiansen G, Winzer KJ, Mayordomo E, Bellach J, Schluns K, Denkert C, Dahl E, Pilarsky C, Altevogt P, Guski H and Dietel M: CD24 expression is a new prognostic marker in breast cancer. Clin Cancer Res 9: 4906-4913, 2003.

7. Surowiak P, Materna V, Paluchowski P, Matkowski R, Wojnar A, Maciejczyk A, Pudelko M, Kornafel J, Dietel M, Kristiansen G, Lage $\mathrm{H}$ and Zabel M: CD24 expression is specific for tamoxifenresistant ductal breast cancer cases. Anticancer Res 26: 629-634, 2006.

8. Bircan S, Kapucuoglu N, Baspinar S, Inan G and Candir O: $\mathrm{CD} 24$ expression in ductal carcinoma in situ and invasive ducta carcinoma of breast: an immunohistochemistry-based pilot study. Pathol Res Pract 202: 569-576, 2006.

9. Lim SC and Oh SH: The role of CD24 in various human epithelial neoplasias. Pathol Res Pract 201: 479-486, 2005.

10. Honeth G, Bendahl PO, Ringner M, Saal LH, Gruvberger-Saal SK, Lovgren K, Grabau D, Ferno M, Borg A and Hegardt C: The $\mathrm{CD} 44^{+} / \mathrm{CD} 24^{-}$phenotype is enriched in basal-like breast tumors. Breast Cancer Res 10: R53, 2008.

11. Athanassiadou P, Grapsa D, Gonidi M, Athanassiadou AM, Tsipis A and Patsouris E: CD24 expression has a prognostic impact in breast carcinoma. Pathol Res Pract 205: 524-533, 2009.

12. Kristiansen G, Denkert C, Schluns K, Dahl E, Pilarsky C and Hauptmann S: CD24 is expressed in ovarian cancer and is a new independent prognostic marker of patient survival. Am J Pathol 161: 1215-1221, 2002

13. Choi YL, Kim SH, Shin YK, Hong YC, Lee SJ, Kang SY and Ahn G: Cytoplasmic CD24 expression in advanced ovarian serous borderline tumors. Gynecol Oncol 97: 379-386, 2005.

14. Surowiak P, Materna V, Kaplenko I, Spaczynski M, Dietel M, Kristiansen $\mathrm{G}$, Lage $\mathrm{H}$ and Zabel M: Unfavorable prognostic value of CD24 expression in sections from primary and relapsed ovarian cancer tissue. Int J Gynecol Cancer 16: 515-521, 2006.
15. Santin AD, Zhan F, Bellone S, Palmieri M, Cane S, Bignotti E, Anfossi S, Gokden M, Dunn D, Roman JJ, O'Brien TJ, Tian E, Cannon MJ, Shaughnessy J Jr and Pecorelli S: Gene expression profiles in primary ovarian serous papillary tumors and normal ovarian epithelium: identification of candidate molecular markers for ovarian cancer diagnosis and therapy. Int $\mathrm{J}$ Cancer 112: 14-25, 2004

16. Winkler A, Zigeuner R, Rehak P, Hutterer G, Chromecki T and Langner C: CD24 expression in urothelial carcinoma of the upper urinary tract correlates with tumour progression. Virchows Arch 450: 59-64, 2007.

17. Choi YL, Lee SH, Kwon GY, Park CK, Han JJ, Choi JS, Choi HY, Kim SH and Shin YK: Overexpression of CD24: association with invasiveness in urothelial carcinoma of the bladder. Arch Pathol Lab Med 131: 275-281, 2007.

18. Karahan N, Guney M, Oral B, Kapucuoglu N and Mungan T: $\mathrm{CD} 24$ expression is a poor prognostic marker in endometrial carcinoma. Eur J Gynaecol Oncol 27: 500-504, 2006.

19. Kim KH, Choi JS, Kim JM, Choi YL, Shin YK, Lee HC, Seong IO, Kim BK, Chae SW and Kim SH: Enhanced CD24 expression in endometrial carcinoma and its expression pattern in normal and hyperplastic endometrium. Histol Histopathol 24: 309-316, 2009

20. Su MC, Hsu C, Kao HL and Jeng YM: CD24 expression is a prognostic factor in intrahepatic cholangiocarcinoma. Cancer Lett 235: 34-39, 2006

21. Baumhoer D, Riener MO, Zlobec I, Tornillo L, Vogetseder A, Kristiansen G, Dietmaier W, Hartmann A, Wuensch PH, Sessa F, Ruemmele P and Terracciano LM: Expression of CD24, P-cadherin and S100A4 in tumors of the ampulla of Vater. Mod Pathol 22: 306-313, 2009.

22. Sagiv E, Memeo L, Karin A, Kazanov D, Jacob-Hirsch J, Mansukhani M, Rechavi G, Hibshoosh H and Arber N: CD24 is a new oncogene, early at the multistep process of colorectal cancer carcinogenesis. Gastroenterology 131: 630-639, 2006.

23. Weichert W, Denkert C, Burkhardt M, Gansukh T, Bellach J, Altevogt P, Dietel M and Kristiansen G: Cytoplasmic CD24 expression in colorectal cancer independently correlates with shortened patient survival. Clin Cancer Res 11: 6574-6581, 2005.

24. Chou YY, Jeng YM, Lee TT, Hu FC, Kao HL, Lin WC, Lai PL, Hu RH and Yuan RH: Cytoplasmic CD24 expression is a novel prognostic factor in diffuse-type gastric adenocarcinoma. Ann Surg Oncol 14: 2748-2758, 2007

25. Kristiansen G, Schluns K, Yongwei Y, Denkert C, Dietel M and Petersen I: CD24 is an independent prognostic marker of survival in nonsmall cell lung cancer patients. Br J Cancer 88: 231-236, 2003

26. Kristiansen G, Pilarsky C, Pervan J, Sturzebecher B, Stephan C, Jung K, Loening S, Rosenthal A and Dietel M: CD24 expression is a significant predictor of PSA relapse and poor prognosis in low grade or organ confined prostate cancer. Prostate 58: 183-192, 2004.

27. Sano A, Kato H, Sakurai S, Sakai M, Tanaka N, Inose T, Saito K, Sohda M, Nakajima M, Nakajima T and Kuwano H: CD24 expression is a novel prognostic factor in esophageal squamous cell carcinoma. Ann Surg Oncol 16: 506-514, 2009.

28. Lee HJ, Kim DI, Kwak C, Ku JH and Moon KC: Expression of CD24 in clear cell renal cell carcinoma and its prognostic significance. Urology 72: 603-607, 2008.

29. Droz D, Zachar D, Charbit L, Gogusev J, Chretein Y and Iris L: Expression of the human nephron differentiation molecules in renal cell carcinomas. Am J Pathol 137: 895-905, 1990.

30. Kwon GY, Ha H, Ahn G, Park SY, Huh SJ and Park W: Role of CD24 protein in predicting metastatic potential of uterine cervical squamous cell carcinoma in patients treated with radiotherapy. Int J Radiat Oncol Biol Phys 69: 1150-1156, 2007.

31. Jacob J, Bellach J, Grutzmann R, Alldinger I, Pilarsky C, Dietel M and Kristiansen G: Expression of CD24 in adenocarcinomas of the pancreas correlates with higher tumor grades. Pancreatology 4: 454-460, 2004.

32. Deichmann M, Kurzen H, Egner U, Altevogt P and Hartschuh W: Adhesion molecules CD171 (L1CAM) and CD24 are expressed by primary neuroendocrine carcinomas of the skin (Merkel cell carcinomas). J Cutan Pathol 30: 363-368, 2003.

33. Schabath H, Runz S, Joumaa S and Altevogt P: CD24 affects CXCR4 function in pre-B lymphocytes and breast carcinoma cells. J Cell Sci 119: 314-325, 2006.

34. Schindelmann S, Windisch J, Grundmann R, Kreienberg R, Zeillinger R and Deissler H: Expression profiling of mammary carcinoma cell lines: correlation of in vitro invasiveness with expression of CD24. Tumour Biol 23: 139-145, 2002. 
35. Sheridan C, Kishimoto H, Fuchs RK, Mehrotra S, Bhat-Nakshatri P, Turner CH, Goulet R Jr, Badve S and Nakshatri H: CD44 + CD24 breast cancer cells exhibit enhanced invasive properties: an early step necessary for metastasis. Breast Cancer Res 8: R59, 2006

36. Abraham BK, Fritz P, McClellan M, Hauptvogel P, Athelogou M and Brauch $\mathrm{H}$ : Prevalence of $\mathrm{CD} 44^{+} / \mathrm{CD} 24^{-/ \text {low }}$ cells in breast cancer may not be associated with clinical outcome but may favor distant metastasis. Clin Cancer Res 11: 1154-1159, 2005.

37. Lee JH, Lee ES and Kim YS: Clinicopathologic significance of BRAF V600E mutation in papillary carcinomas of the thyroid: a meta-analysis. Cancer 110: 38-46, 2007.
38. Hurt EM, Kawasaki BT, Klarmann GJ, Thomas SB and Farrar WL: CD44 ${ }^{+}$CD24(-) prostate cells are early cancer progenitor/stem cells that provide a model for patients with poor prognosis. Br J Cancer 98: 756-765, 2008.

39. Li C, Heidt DG, Dalerba P, Burant CF, Zhang L, Adsay V, Wicha M, Clarke MF and Simeone DM: Identification of pancreatic cancer stem cells. Cancer Res 67: 1030-1037, 2007. 